\title{
Prospects of Solar Energy in Bangladesh
}

\author{
Anik Deb, Dr. Mahmud Abdul Matin Bhuiyan, Arefin Nasir \\ Department of Electrical and Electronic Engineering, Chittagong University of Engineering and Technology, \\ Bangladesh
}

\begin{abstract}
A reliable, affordable and secure supply of energy is important for socio-economic development. As a country of acute power crisis Bangladesh is now looking forward to develop its renewable energy sources in addition to its traditional sources of fossil fuel. It has very limited non renewable energy sources of its own but it's endowed with renewable energy sources like biomass, wind, hydro and solar insolation. The following research paper is based on the prospects of solar energy from perspective of Bangladesh. Possible implementations of solar technologies like photovoltaic cells $(P V)$ and Solar thermal energy (STE) are discussed with their optimum capacity, efficiency, storage facility and cost per unit power. Some social, economic and environmental constraints regarding the implementation of solar technology are highlighted and some possible solutions are offered.
\end{abstract}

Keywords- DC micro grid, Irrigation, Solar energy, Solar Based Recharging Stations, Solar cooking

\section{INTRODUCTION}

The global warming due to greenhouse gas emission and the energy scarcity worldwide are prompting almost all the countries in the world to look for alternative sources of energy such as nuclear and renewable such as solar, wind, geo-thermal and wave energies, which do not cause carbon emission. Whereas developed countries can tap into nuclear energy [1], a developing country like Bangladesh is not fortunate enough to have that option available. Consequently, the only option that is open to Bangladesh at the moment is renewable energy such as solar and hydro-electric. Bangladesh is a semi-tropical region lying in northeastern part of South Asia gets abundant sunlight year round. The average bright sunshine duration in Bangladesh in the dry season is about 7.6 hours a day, and in the monsoon season is about 4.7 hours. Solar energy can be harnessed in two ways:

a) Photovoltaic Cells (PV) and

b) Solar thermal energy (STE) [2].

In general, a solar cell or photovoltaic cell (PV) is a solid state electrical device that converts light into electric current using the photoelectric effect. Materials presently used for photovoltaic solar cells include mono-crystalline silicon, polycrystalline silicon, amorphous silicon, cadmium telluride, and copper indium selenide/sulfide. Different materials offer varying level of efficiencies, with the current average efficiency of a solar cell ranging from $8 \%-20 \%$. Historically, most PV panels have been used for off-grid purposes, thus it can be seen as a means of avoiding construction of long and expensive power lines to remote areas. Off grid PV systems have normally use storage devices (Battery) to store excess electricity which can run the cell for a few hours in the absence of sunlight. [3] On the other hand solar thermal energy is a form of energy in which the sun is used to produce heat that can be used in a variety of ways. For thousands of years ,people have been using this energy for a variety of tasks, and modern technology has considerably expanded the applications for the sun's heat. [4]

\section{Potential Of Solar Energy In Bangladesh (Environmental Analysis):}

Bangladesh is located between $20^{\circ} 30^{\prime}$ and $26^{\circ} 45^{\prime}$ north latitude and has a total area of $1.49 \mathrm{E}+11$ $\mathrm{m}^{2}$.An average of $5 \mathrm{kWh} / \mathrm{m}^{2}$ solar radiation falls on this land over 300 days per annum. Maximum amount of radiation is available on the month of March-April and minimum on December-January. A 2012 study found the daily sunlight hours in Bangladesh to range from 10 to 7 hours; they further reduced this by 54\% (to 4.6 hours) to account for rainfall, cloud, and fog [4-5]. So this abundant solar energy have a large potential to be used in various sector in Bangladesh reducing the traditional fossil fuel based power consumption and ensuring a green environment for the future generation.

\section{Prospects Of Solar Energy In Bangladesh:}

Bangladesh is a potential ground for applying solar energy in different aspect using both solar PV and STE technology. Some applications specially designed for Bangladesh is described below. 


\subsection{Solar Based Recharging Stations for Electric Vehicles:}

Currently two types of electrical verticals are running in our country. One is locally called "easy bike". It looks closely like traditional CNG based auto rickshaw except its run on battery. The second one is two seated rickshaw. Both of them are energy efficient and environment friendly being popular in the world as well as Bangladesh. Typically they run on $50 \mathrm{Ahr} .80 \mathrm{Ahr}, 100 \mathrm{Ahr}$ and $120 \mathrm{Ahr}$ battery based on the size and speed of the vehicle. Currently there is no known recharging station for charging them as it consumes lots of power from Grid. So here we propose a Solar PV based electrical vehicle Recharging station. This process can run alongside the Normal CNG filling station or petrol pump, as the solar panels would be mounted on top of it. This method can work in almost every part of Bangladesh as the whole country face almost same solar insolation enough to produce required electrical energy.
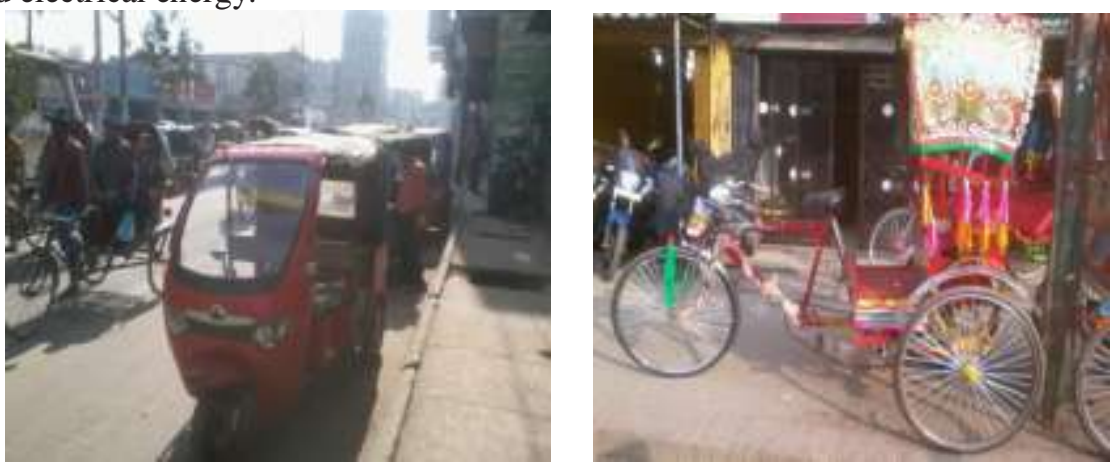

Fig. 1: Electric vehicles in Bangladesh

\subsubsection{System design:}

The PV modules are accommodated on the roof of fuel filing stations. Generally the roof is plain as a result there is no problem to set up but for maximum efficiency.

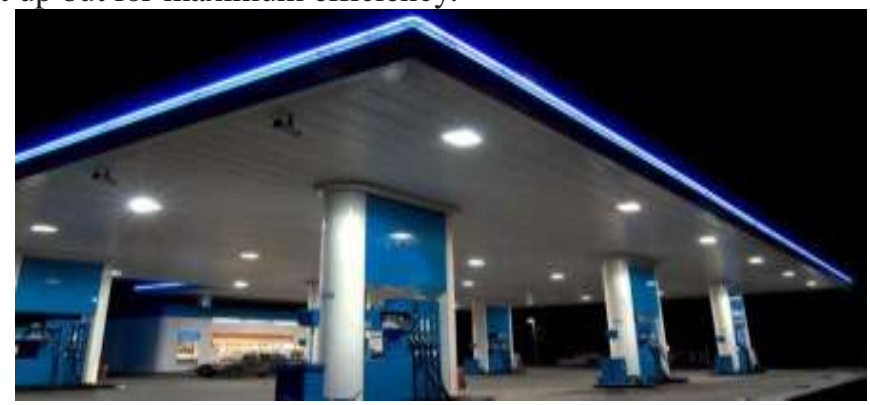

Fig.2: A general fuel filling station

PV modules are tilted with an angle which depends on the location of the installation. For Bangladesh the optimum tilt angle is around $23^{\circ}[6]$.Capacity of the PV module should be selected taking in consideration the rooftop size for accommodating the panels and the desired output. For example charging 10 electric vehicles at a time would require about $10 \mathrm{KW}$ power supply. Because charging the battery of each vehicle will take 850 1000W initially. DC combiner box will also be placed on the roof of the fuel filling stations. The control sections control the whole system which is connected or interfaced with the output devices or a Personnel Computer. There will also be a meter which continuously measures the electrical supply and the data is sent to displaying unit. This unit may be a Personnel Computer or other display unit. If it is PC, there is an advantage that the data will be gathered .As the battery is DC powered there is no need to attach with any inverter.

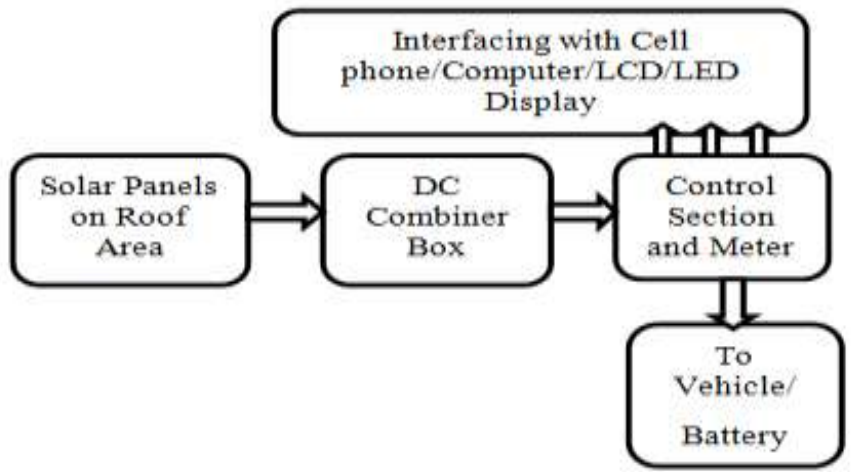

Fig 3: Total system's block diagram [7]. 


\subsubsection{Cost Analysis:}

The cost of these components may be varied depending on its brand, quality, place and quantity. Here we have taken $15 \mathrm{KWp}$ solar panel each of $100 \mathrm{Wp}$ to get a minimum supply of $8 \mathrm{KWp}$ throughout the day. Sizing was determined By HOMAR Simulation software for renewable energy putting the solar insolation of Chittagong city as input parameter .Maximum output would be greater when the solar radiation is high. Costs of components were taken from local market.

Table-1: Cost of components for Solar based recharging stations

\begin{tabular}{|l|l|l|l|}
\hline Component & Description & Quantity & $\begin{array}{l}\text { Cost in taka } \\
(1 \text { US \$=80 taka) }\end{array}$ \\
\hline PV modules (15KW) & Local market & $\begin{array}{l}150 \text { module } \\
(100 \mathrm{Wp}) \\
\text { (Estimated) }\end{array}$ & $\begin{array}{l}150 \times 9,500 \\
=14,25,000\end{array}$ \\
\hline Combiner boxes & $\begin{array}{l}\text { Midnite Solar } \\
\text { MNPV3[8] }\end{array}$ & $\begin{array}{l}8 \times 5500 \\
=44,000\end{array}$ \\
\hline Charge controller & Local market & 1 & 2,000 \\
\hline Wiring & Approximate & & 5,000 \\
\hline $\begin{array}{l}\text { Control circuit, } \\
\text { installment, maintenance } \\
\text { and others. }\end{array}$ & Approximate & & 50,000 \\
\hline Total & & & $15,26,000$ \\
\hline
\end{tabular}

\subsubsection{Daily and monthly Electricity Generation and Income}

In our system the estimated capacity is around $8 \mathrm{~kW}$. So to find out the daily energy generation we have to multiply this number to monthly average sunshine duration. Again for finding the monthly energy generation we have to multiply daily energy generation to number of days of each month respectively [4]. The calculated data is shown in Table 2

Table -2 Daily and Monthly Average Electricity Generations in KWh

\begin{tabular}{|l|c|c|c|}
\hline Month & $\begin{array}{l}\text { Sunshine } \\
\text { duration }(\mathrm{hr})\end{array}$ & $\begin{array}{l}\text { Daily energy } \\
\text { generation }(\mathrm{kWh})\end{array}$ & $\begin{array}{l}\text { Monthly energy } \\
\text { generation }(\mathrm{kWh})\end{array}$ \\
\hline January & 8.7 & 69.6 & $2,157.6$ \\
\hline February & 9.1 & 72.8 & $2,038.4$ \\
\hline March & 8.8 & 70.4 & $2,182.4$ \\
\hline April & 8.9 & 71.2 & 2,136 \\
\hline May & 8.2 & 65.6 & $2,033.6$ \\
\hline June & 4.9 & 39.2 & 1,176 \\
\hline July & 5.1 & 40.8 & $1,264.8$ \\
\hline August & 5.8 & 46.4 & $1,438.4$ \\
\hline September & 6.0 & 48.0 & 1,4880 \\
\hline October & 7.6 & 60.8 & 1,824 \\
\hline November & 8.6 & 68.8 & $2,132.8$ \\
\hline December & 8.9 & 71.2 & 2,136 \\
\hline Total & & & 22,008 \\
\hline
\end{tabular}

From Table- 2 we can easily get the monthly energy generation. From monthly energy generation we can calculate the monthly income and the summation of monthly income is referred to annual income which helps us to find payback time of our proposed system. In Table 2 the monthly incomes are shown which is calculated in different consideration

Table 3: Monthly and yearly income

\begin{tabular}{|l|l|l|l|l|}
\hline Month & $\begin{array}{l}\text { Energy } \\
\text { generation } \\
(\mathrm{KWh})\end{array}$ & $\begin{array}{l}\text { Income } \\
(1 \mathrm{KWh}=8 \text { Taka })\end{array}$ & $\begin{array}{l}\text { Income } \\
(1 \mathrm{KWh}=10 \text { Taka })\end{array}$ & $\begin{array}{l}\text { Income } \\
(1 \mathrm{KWh}=12 \text { Taka })\end{array}$ \\
\hline January & $2,157.6$ & $17,260.8$ & 21,576 & 25,891 \\
\hline February & $2,038.4$ & 16307.2 & 20,384 & 24,461 \\
\hline March & $2,182.4$ & 17459.2 & 21,824 & 26,188 \\
\hline April & 2,136 & 17088 & 21,360 & 25,632 \\
\hline
\end{tabular}


Prospects of Solar Energy in Bangladesh

\begin{tabular}{|l|l|l|l|l|}
\hline May & $2,033.6$ & 16268.8 & 20,336 & 24,403 \\
\hline June & 1,176 & 9408 & 11,760 & 14,112 \\
\hline July & $1,264.8$ & 10118.4 & 12,648 & 15,178 \\
\hline August & $1,438.4$ & 11507.2 & 14,384 & 17,261 \\
\hline September & 1,488 & 11904 & 14,880 & 17,856 \\
\hline October & 1,824 & 14592 & 18,240 & 21,888 \\
\hline November & $2,132.8$ & 17062.4 & 21,328 & 25,594 \\
\hline December & 2,136 & 17088 & 21,360 & 25,632 \\
\hline \multicolumn{2}{|l|}{ Total(Yearly income) } & $1,76,064$ & $2,20,080$ & $2,64,096$ \\
\hline
\end{tabular}

2.1.4 Payback period analysis

The payback period means that the number of years required recovering the cost of the investment and for cost benefit analysis of our system it is needed [9]. Here we have to consider eight, ten, twelve taka per kilowatt hour as the fuel price as well as the electricity price is increased day by day. Considering eight, ten and twelve taka per kilowatt hour it is estimated that the payback time in year around nine, seven, and six respectively.

Considering $1 \mathrm{~kW}-\mathrm{hr}=8$ taka:

Total cost of the system $=15,26,000$ taka

Annual income $=176,064$ taka

So, payback period in year $=\frac{\text { Cost of the system }}{\text { Annual income }}=\frac{15,26,000}{1,76,064}=8.67 \approx 9$ years

Considering $1 \mathrm{~kW}-\mathrm{hr}=10$ taka:

Total cost of the system $=15,26,000$ taka

Annual income $=2,20,080$ taka

So, payback period in year $=\frac{\text { Cost of the system }}{\text { Annual income }}=\frac{15,26,000}{2,20,080}=6.93 \approx 7$ years

Considering $1 \mathrm{~kW}-\mathrm{hr}=12$ taka:

Total cost of the system $=15,26,000$ taka

Annual income $=2,64,096$ taka

So, payback period in year $=\frac{\text { Cost of the system }}{\text { Annual income }}=\frac{15,26,000}{2,64,096}=5.77 \approx 6$ years

\subsubsection{Opportunities and Benefits:}

- $300 \mathrm{MW}$ to $500 \mathrm{MW}$ power was used every day to recharge an Easy-bike and in most cases it was done illegally. Using this theme this problem can overcome.[4]

- Recharging an eclectic vehicle will cost maximum 32-40 taka.

- Investment is lesser than other solar project because of not using inverter circuit and Battery Bank.

\subsubsection{Challenges and Limitations}

- Initial cost is high for the owner of the fuel filling stations.

- Lack of knowledge about clean renewable energy technologies.

- Lack of awareness of future development.

- During nighttime and in insufficient solar radiation the system will not work.

\subsection{Solar PV Based Irrigation in Rural Bangladesh and Solar DC Micro-grid}

Irrigation problem is the most acute problem of Bangladesh being a agricultural county. About 3,36,000 pump are used during dry seasons for irrigation purpose.[10] About 50\%[11] people living in this country are off-grid and mostly use diesel generator for irrigation. People of on-grid use $1700 \mathrm{Mw}$ of power only for irrigation purpose, creating load shedding throughout the nation. So we need to look for an alternative solution.

Solar PV based irrigation is not a new concept and there are already a number of such irrigation schemes running in Bangladesh. Technologically, it is not a big challenge, as it does not require any highly sophisticated component. However, the main challenge comes from the actual cost of irrigation which is heavily dependent on the irrigation model in the context of the socio-economic condition of rural Bangladesh. [12-15] as irrigation requirements are quite severe only during the dry months (3-4 months) [16] the over head cost becomes too high for dedicated irrigation projects.

During last 5-6 years, Solar Home Systems (SHS) has seen a tremendous growth in rural Bangladesh and it reflects the attitude of the rural people towards a viable energy alternative.[17]Unfortunately, energy output in a SHS is very low and is barely enough to meet the basic household need like lighting. A SHS is not designed to provide energy support even to small scale cottage industry. Hence, we must look at other possible 
alternative models for powering the irrigation pumps. A viable alternative is micro-grid system where standalone small size grids are designed to provide power to small rural areas from a centrally located power station. These power stations could be solely solar PV, or solar PV-Diesel hybrid [18]. There can be two options so far the design of the micro-grids are concerned 1) AC micro grid and 2) DC micro-grid

\subsubsection{Project site}

To examine the output of Solar -PV DC grid to solve the problem of irrigation in off-grid area and serving the domestic loads of the village, we have taken a model named Sandip-para which lies in Raujan Upazila. (Latitude: 22.354265, Longitude: 91.838051)[18]

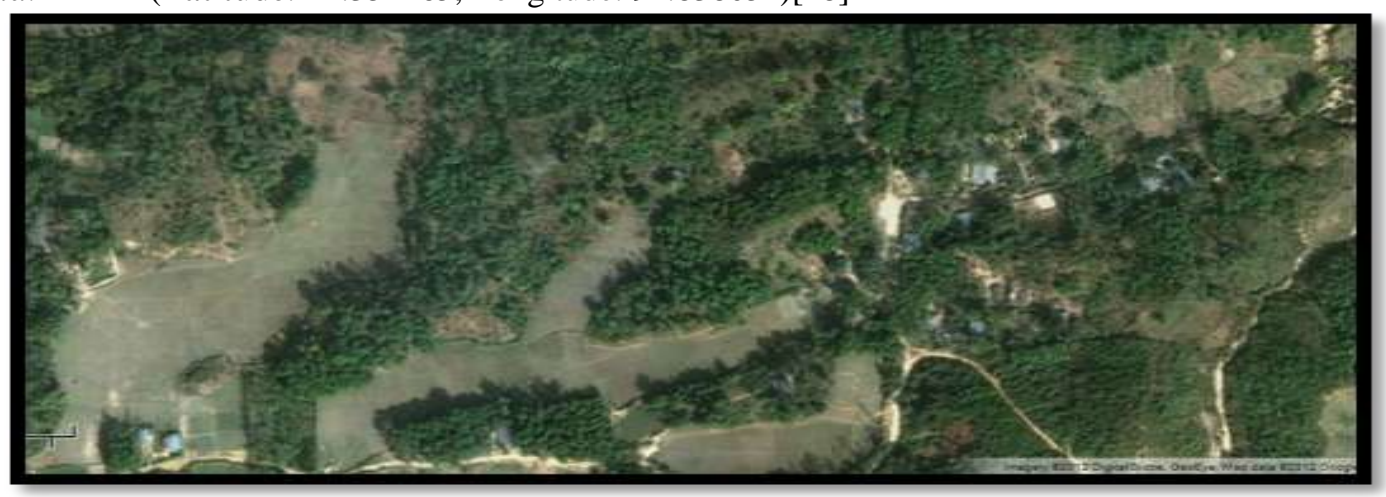

Fig. 4: Sandip-para - a top view from Google Earth. [20]

Sandip-para is one of the non grid-connected areas of Bangladesh and about 30 families live here. It is surrounded by hilly areas and most of the people are farmers and dependent upon agriculture for their livelihood. The people of this region experience the continuous daylight throughout the year although the solar radiation of winter season remains comparatively low than that of summer season. The average solar insolation intensities of about $4.758 \mathrm{KWh} /$ day with average sunshine hour of 5.8 hours/day of about 300 days of sun a year is available in this region.

\subsubsection{Load Estimation:}

\subsubsection{Loads (July-October)}

Electricity demand for each family: [21]

Two CFL bulb $=12$ (power rating of each bulb) $\times 2$ (no. of bulb) $\times 6$ (hours of operation $)=144 \mathrm{Wh}$

Two Fan $=20$ (power rating of fan $) \times 2$ (no. of fan $) \times 6$ (hours of operation $)=240 \mathrm{Wh}$

One Radio set $/ \mathrm{TV}$ set $(\mathrm{B} \& \mathrm{~W})=25($ power rating of TV $) \times 1($ no. of TV $) \times 2($ hours of operation $)=50 \mathrm{Wh}$

Thus, from the above estimation, Peak Watt demand for each family $(\mathrm{Wp})=89 \mathrm{~W}$

Total demand of each family per day $=434 \mathrm{Wh} /$ day

Electricity demand for a mosque:

Two CFL bulb $=12$ (power rating of each bulb) $\times 2$ (no. of bulb) $\times 2$ (hours of operation $)=48 \mathrm{Wh}$

Two Fan $=20$ (power rating of fan) $\times 2$ (no. of fan) $\times 2$ (hours of operation $)=80 \mathrm{Wh}$

Peak Watt demand for the mosque $\left(\mathrm{W}_{\mathrm{p}}\right)=64 \mathrm{~W}$

Total demand of mosque per day $=128 \mathrm{Wh} /$ day

Electricity demand for a school:

Four CFL bulb $=12$ (power rating of each bulb) $\times 4$ (no. of bulb) $\times 6$ (hours of operation $)=288 \mathrm{Wh}$

Four Fan $=20$ (power rating of fan) $\times 4$ (no. of fan $) \times 6$ (hours of operation $)=480 \mathrm{Wh}$

Peak Watt demand for the school $\left(\mathrm{W}_{\mathrm{p}}\right)=128 \mathrm{~W}$

Total demand of school per day $=768 \mathrm{Wh} /$ day

Hence, Maximum demand of energy per day $=(434 \times 30)+128+768=13916 \mathrm{Wh} /$ day $=13.91 \mathrm{KWh} /$ day

Fig.5 is showing load duration curve for July-October

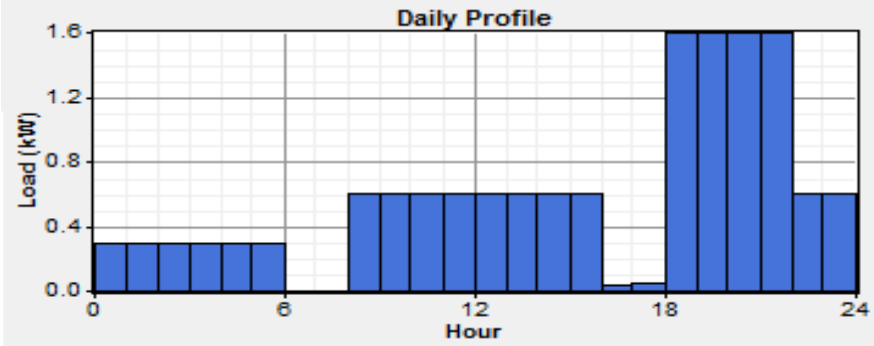

Fig. 5: Daily Load Profile (July-October) 


\subsubsection{Loads during dry season (March-June):}

Solar insolation throughout the year, in this area is given in table-3.From there we can see during March-June the solar radiation remains high, mostly above $5 \mathrm{KWh} / \mathrm{m}^{2} /$ day. This is the Dry season when farmers need irrigation. So harnessing this excess power we can solve our irrigation problem and at the same time supply some basic loads for the village.

Considering the area of cultivating land in Sandip-para have selected 2 pump each of 1 H.P that is $=746$ Watts. [22-23]

Two pump $=746$ (power rating of each pump) $\times 2$ (no. of motor $) \times 8$ (hours of operation $)=11936 \mathrm{Wh} /$ day . Generally all the water pumps available for irrigation in local market are AC pumps. In that case the system will need an inverter for the pumps.

Other consumptions will be most basic loads of the village. For example, all CFL bulbs for domestic purpose and occasional use of fan, as maximum power will be consumed for irrigation purpose.A typical load duration curve clarifying the consumption of energy per hour of the day for a day in the month of March (Dry season) is shown in Fig.6

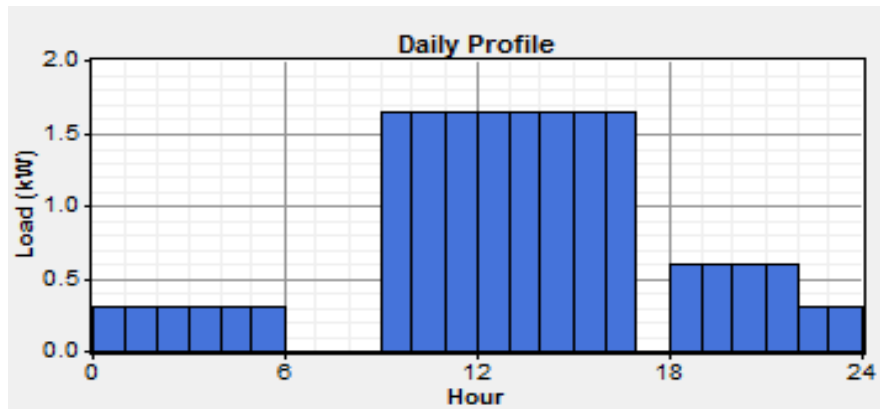

Fig. 6: Daily Load Profile (Dry Month)

\subsubsection{Load during winter (November-February)}

In this period of the year, there will be no loads of fan. Almost all the other loads will remain same as July-October. Hence total Energy demand of the village is $578 \mathrm{Wh} /$ day.Fig.7 is showing load duration curve for November-February and the load profile for the whole year is shown in Fig.8

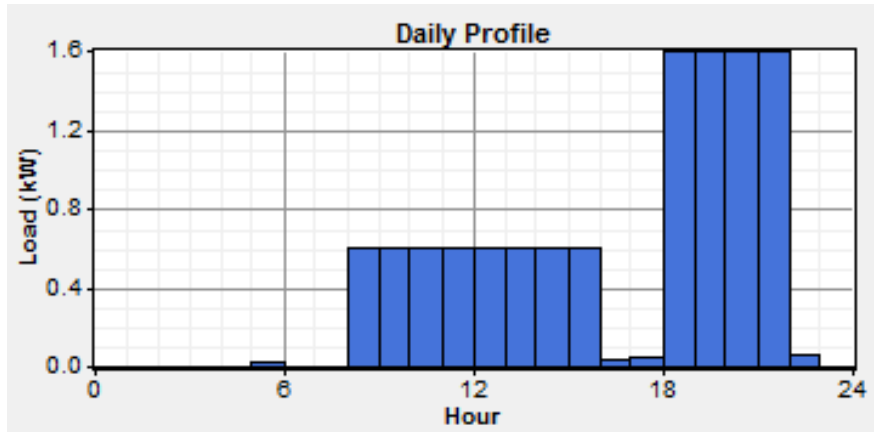

Fig.7: Daily Load Profile of winter period (November- February)

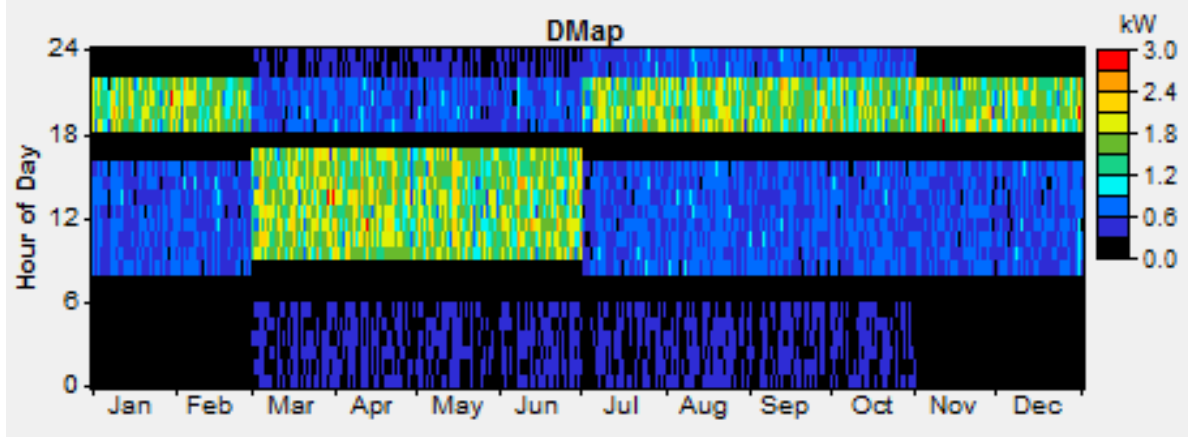

Fig. 8: Load profile of day throughout the year 


\subsection{3 .Simulation by HOMER:}

\subsubsection{Input Parameters for Solar PV scheme:}

The solar resource input for the various months throughout the year was obtained from the internet via HOMER software by providing the latitude, longitude and time zone information. [24]

Location of the site: Latitude $22^{\circ} 28^{\prime}$ North

Longitude: $91^{\circ} 58^{\prime}$ East

Time Zone: [GMT+06:00]

The solar radiation data for various months throughout the year in Raujan is shown in Table 4 below.

Table 4: Solar radiation throughout the year

\begin{tabular}{|l|l|l|}
\hline Month & Clearness Index & Daily Radiation $\left(\mathrm{KW} / \mathrm{m}^{2} / \mathrm{d}\right)$ \\
\hline January & 0.646 & 4.597 \\
\hline February & 0.628 & 5.126 \\
\hline March & 0.596 & 5.634 \\
\hline April & 0.550 & 5.760 \\
\hline May & 0.527 & 5.786 \\
\hline June & 0.390 & 5.786 \\
\hline July & 0.368 & 4.335 \\
\hline August & 0.398 & 4.048 \\
\hline September & 0.418 & 4.224 \\
\hline October & 0.555 & 4.083 \\
\hline November & 0.601 & 4.725 \\
\hline December & 0.649 & 4.409 \\
\hline Average & 0.513 & 4.758 \\
\hline
\end{tabular}

The solar radiation for each month was obtained where it was found that the maximum solar radiation was found for the month of May and June with daily radiation of $5.786 \mathrm{KWh} / \mathrm{m}^{2} /$ day whereas the minimum radiation was found for the month of August with daily radiation of $4.048 \mathrm{KWh} / \mathrm{m}^{2} /$ day. The average radiation throughout the year was $4.758 \mathrm{KWh} / \mathrm{m}^{2} /$ day.

\subsubsection{Storage Device:}

Solar PV thus storage device is also modeled so that the energy from solar panels can be stored in battery and it can be used whenever the solar radiation is weak or when the generation is not feasible from solar cells, such as during cloudy days, rainy days. The storage device can also be used as the source of energy during the period of night. As the terminal voltage of the individual battery is $12 \mathrm{~V}$ hence to get $12 \mathrm{~V}$ bus single battery per string is used.

\subsubsection{Generation cost:}

Its need to be noted that the price listed in Table 3 are taken as a unit price of the equipments used in our system rather than the whole system as a input parameter. It's done by collecting data from local market for the individuals.

Table 5: Cost of the components taking as input for simulation

\begin{tabular}{|l|l|l|l|l|}
\hline Equipment & Size/Quantity & Capital & Replacement & O\&M(Tk/yr $)$ \\
\hline Solar panel & $1000 \mathrm{~W}$ & 180000 & 160000 & 20 \\
\hline Storage device & 1 & 10000 & 8000 & 200 \\
\hline
\end{tabular}

\subsubsection{Model of Micro DC Grid system:}

Solar PV scheme is alone contributing generation operation of this system. Storage device storing of power produced from solar panel. The below Fig. 8 shows complete model that is delivering power to the loads. The total system is connected to DC bus bar. 


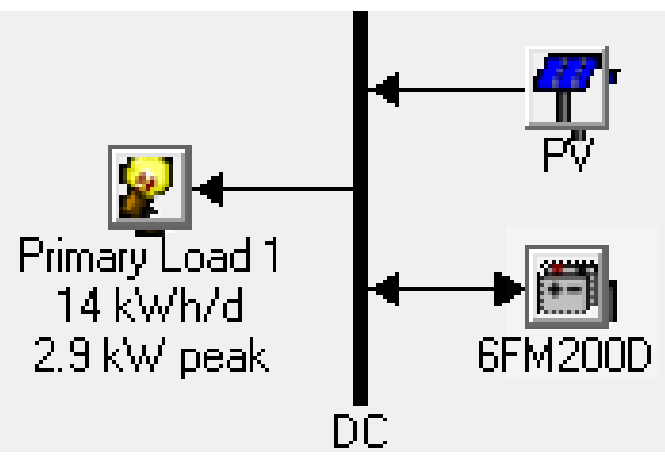

Fig 9: Complete Model of PV System

Here, by the HOMER software the simulated peak demand of primary load is $2.9 \mathrm{KW}$ and total energy consumption is $14 \mathrm{kWh} /$ day where calculated peak demand is $2.8 \mathrm{~kW}$ and total energy consumption is 13.9 $\mathrm{kWh} / \mathrm{day}$. Simulated result is almost equal to calculated result as we given balanced input load to the HOMER software of different hours of a day.

\subsubsection{Simulation results for Solar PV System:}

Simulation results found from simulation for PV array is summarized below in table: 6:

Table 6: PV scheme results

\begin{tabular}{|l|l|l|}
\hline Quantity & Value & Units \\
\hline Rated capacity & 8.00 & $\mathrm{~kW}$ \\
\hline Mean output & 1.38 & $\mathrm{~kW}$ \\
\hline Mean output & 33.00 & $\mathrm{~kW} / \mathrm{d}$ \\
\hline Capacity factor & 17.2 & $\%$ \\
\hline Minimum output & 0.00 & $\mathrm{~kW}$ \\
\hline Maximum output & 7.94 & $\mathrm{~kW}$ \\
\hline PV penetration & 238 & $\%$ \\
\hline Hours of operation & 4373 & $\mathrm{hr} / \mathrm{yr}$ \\
\hline Level zed cost & 4.68 & $\mathrm{Tk} / \mathrm{kWh}$ \\
\hline
\end{tabular}

\subsubsection{Simulation Results for Storage Device:}

Vision 6FM200D [25] Battery was used as storage device for the Solar PV system. The capacity of each battery was 200Ah. The simulation result for battery is given below in Table.7.

Table 7: Storage Device results

\begin{tabular}{|l|l|l|}
\hline Quantity & Value & Units \\
\hline Nominal capacity & 21.6 & $\mathrm{kWh}$ \\
\hline Usable nominal capacity & 13.0 & $\mathrm{kWh}$ \\
\hline autonomy & 64.7 & $\mathrm{hr}$ \\
\hline Lifetime throughput & 8,253 & $\mathrm{Tk} / \mathrm{kWh}$ \\
\hline Battery wear cost & 9,754 & $\mathrm{Tk} / \mathrm{kWh}$ \\
\hline Energy In & 1,187 & $\mathrm{kWh} / \mathrm{yr}$ \\
\hline Energy Out & 952 & $\mathrm{kWh} / \mathrm{yr}$ \\
\hline Storage depletion & 3 & $\mathrm{kWh} / \mathrm{yr}$ \\
\hline Losses & 232 & $\mathrm{kWh} / \mathrm{yr}$ \\
\hline Annual throughput & 1,065 & $\mathrm{kWh} / \mathrm{yr}$ \\
\hline
\end{tabular}

\subsection{Cost Summary of PV System}

The cost summary of PV system after simulation in terms of Net Present cost by component size and cost type obtained after simulation is given below in Fig.10 and Fig.11 respectively 


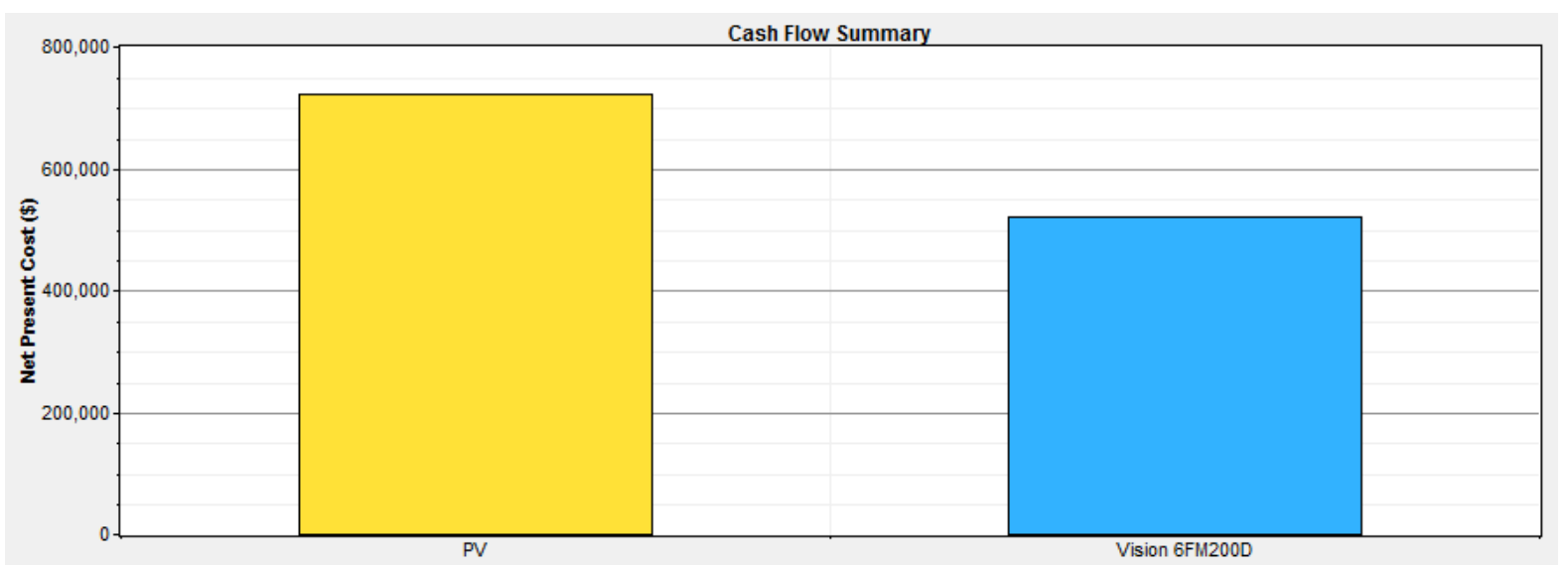

Fig 10: Cash Flow Summary by Component type

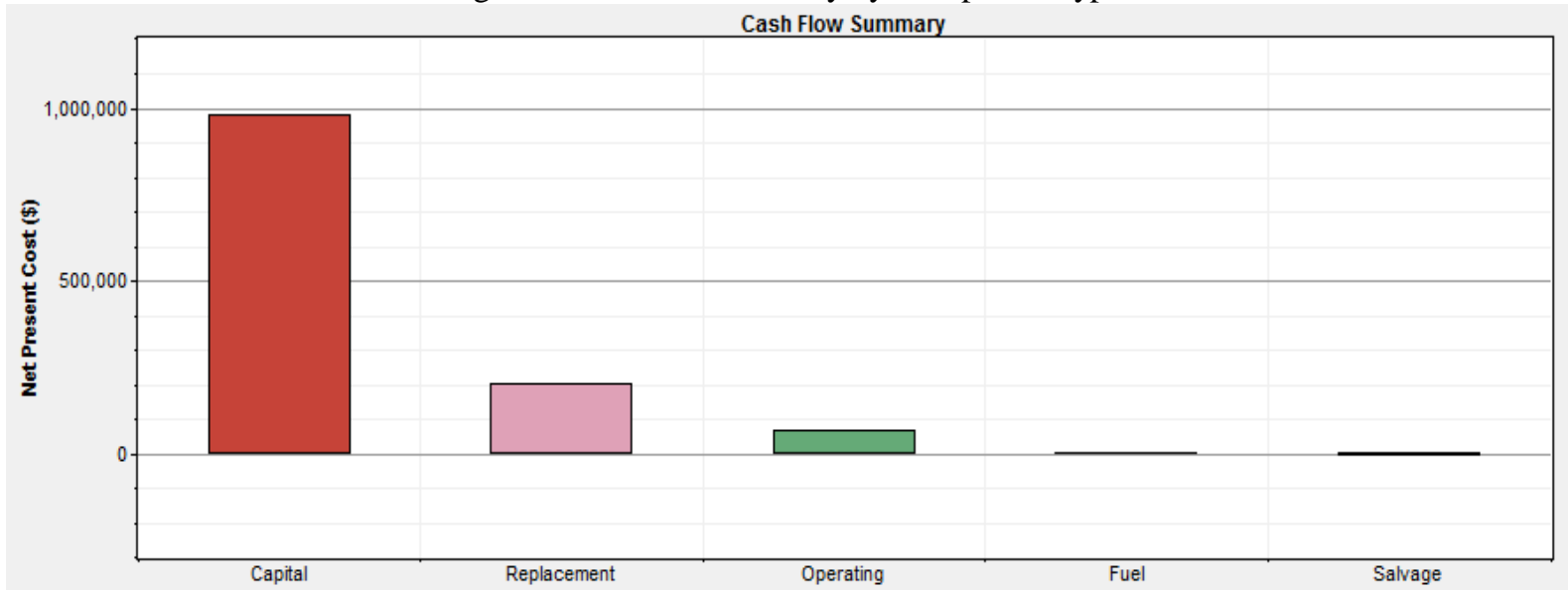

Fig 11: Cash Flow Summary by Cost type

\subsubsection{Summarized results:}

Solar PV system architecture:

8KW Solar PV

26 battery of Vision 6FM200D

PV array Production: 12,056 kWh/yr

DC primary load Consumption: $5,070 \mathrm{kWh} / \mathrm{yr}$

Total Net Present Cost (NPC): 12, 42,715Tk

Level zed Cost of Energy (COE): 19.175Tk/kWh (.231 US \$)

Operating Cost: 20,551Tk/yr.

\subsubsection{Interpretation of result:}

Here we have tried to standardize a model to solve the irrigation problem as well as enlightening the off grid area by serving Solar PV based Green energy. We have considered all the basic loads of a rural area and simulated it for the desired system. The levelized cost of the simulated system is $19.175 \mathrm{Tk} / \mathrm{kWh}$ with initial cost of $12,42,715 \mathrm{Tk}$ (.231 US \$). Operating and maintenance cost will vary with maximum value of 20,551Tk/yr. This price is higher than the current on grid electricity but this system can provide energy security for 25 years. So we considering this scheme will prove beneficiary in near future.

\subsection{Solar Cooking and Its Prospects in Bangladesh}

A solar cooker is a device that uses sunlight to produce heat in order to cook food. Solar cooking is the cleanest and safest mode of cooking. It utilizes solar energy which is abundantly available in nature to cook food. There are three major types of solar cookers [26]:
a) Box-type solar cooker
b) Panel-type solar cooker
c) Parabolic reflector solar cooker
a. Box-type solar cooker:

The box cooker is one of the most widely used solar cooker types. It consists of a well insulated box with a transparent lid, usually made of glass or plastic. The lids are sometimes glazed and additional reflectors are used 
so as to increase the incident radiation and, at the same time, decrease the heat loss into the surrounding air. Food is kept in a black (or very dark) cooking pot and placed inside the box cooker. The box cooker uses the principle of greenhouse effect to cook the food contained in it. [26] A solar box cooker with adjustable reflector and absorber plate is given below in Fig 12:

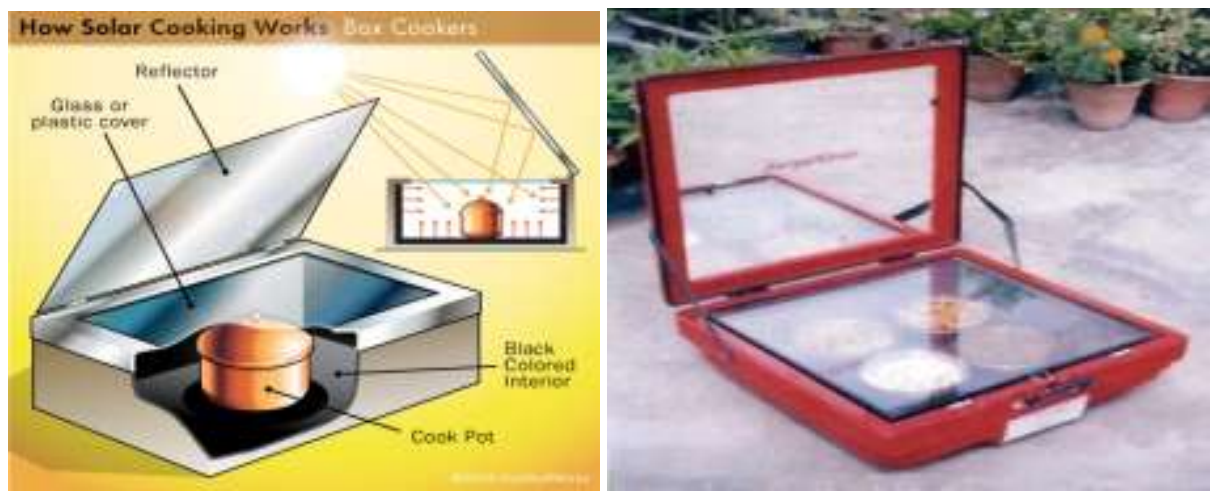

Fig.12 Solar box cooker with adjustable reflector and absorber plate

b. Panel-Type Solar Cooker:

A panel-type solar cooker is a very simple and inexpensive form of solar cooker. It uses reflective panels to direct sunlight towards a transparent, plastic bag containing the cooking vessel (painted black). It uses the same heat trapping principle as the box cooker, except that instead of a box, the cooking vessel is kept in a tightly closed transparent bag. A panel cooker relies on focusing sunlight towards the transparent bag by using multifaceted reflective panels. [26]A Panel-Type Solar Cooker is shown in Fig: 13.

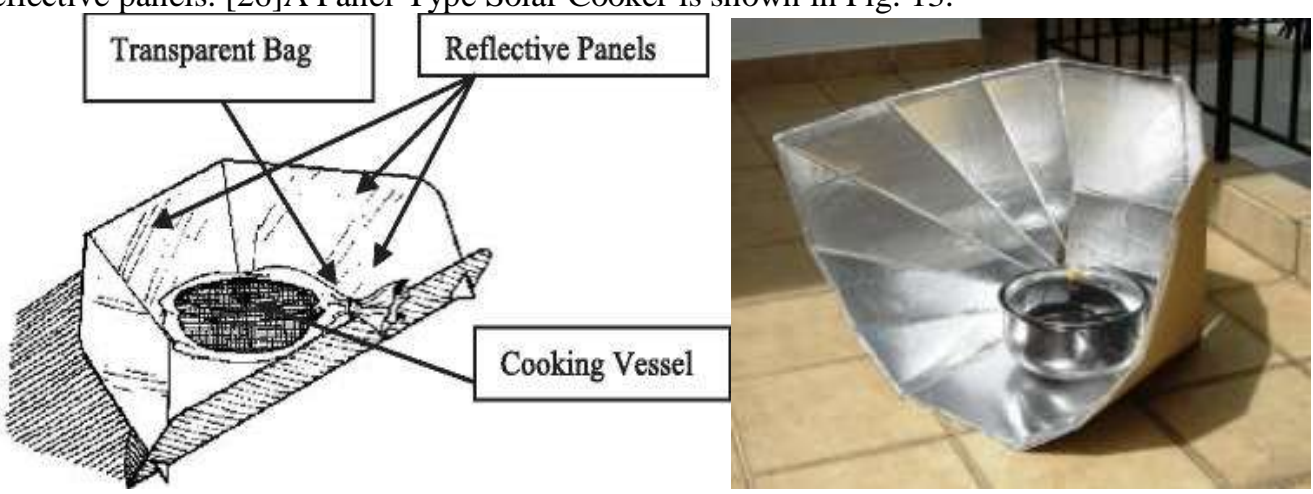

Fig 13.Panel-Type Solar Cooker

c. Parabolic Reflector Solar Cooker:

The parabolic reflector solar cooker uses reflective metal sheets and/or lenses to cook food. It uses the principle of concentrating optics and needs to be properly aligned to follow sun's motion in the sky from time to time. The concentrated sun's rays must be exactly directed at the position where the cooking vessel is kept.
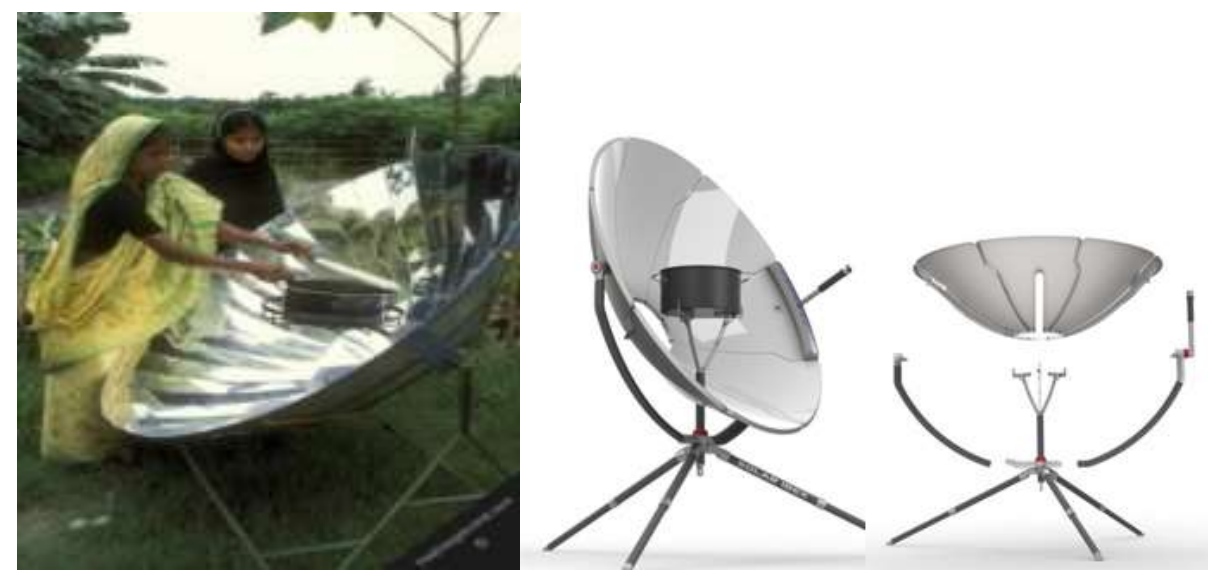

Fig.14 Parabolic Reflector Solar Cooker 


\subsubsection{Advantages of solar cooking:}

There are several advantages of implementing a countrywide solar cooking practice:

- Reduction of Deforestation: In Bangladesh, 40 million tones of firewood are burnt for cooking causing air pollution. Solar cooking neither produces smoke nor involves cutting down of trees.

- Reduction of GHG emission: By burning $1000 \mathrm{~kg}$ of firewood, $1900 \mathrm{~g}$ of carbon dioxide gas is released into the atmosphere. Burning of 1000 cubic feet of natural gas produces 55,622.38 g of carbon dioxide. As previously mentioned, solar cooking does not emit any greenhouse gas.[27]

- Gas Crisis Mitigation: The total number of gas connections is 23, 25,456 If such a household uses a solar cooker on every sunny day, it is possible for that household to save about $94.49 \times 145=13,701$ cubic feet of natural gas per annum.

- Health issues and safety reasons: Burning firewood or Combustion of gas releases nitrogen dioxide, sulphur dioxide and also formaldehyde, which, if inhaled over a long period of time, results in asthma, wheeze and even lung cancer. Occasional accidents also led to fatal consequences[28]

\subsubsection{Potential of solar cooking in Bangladesh}

Using solar radiation data for Bangladesh, the graph in Fig.15 has been plotted. From this graph, it is found that there are on average 294 and 145 days in a year when the global horizontal radiation and the direct normal radiations respectively are above $4.0 \mathrm{KWh} / \mathrm{m}^{2}$ [27].

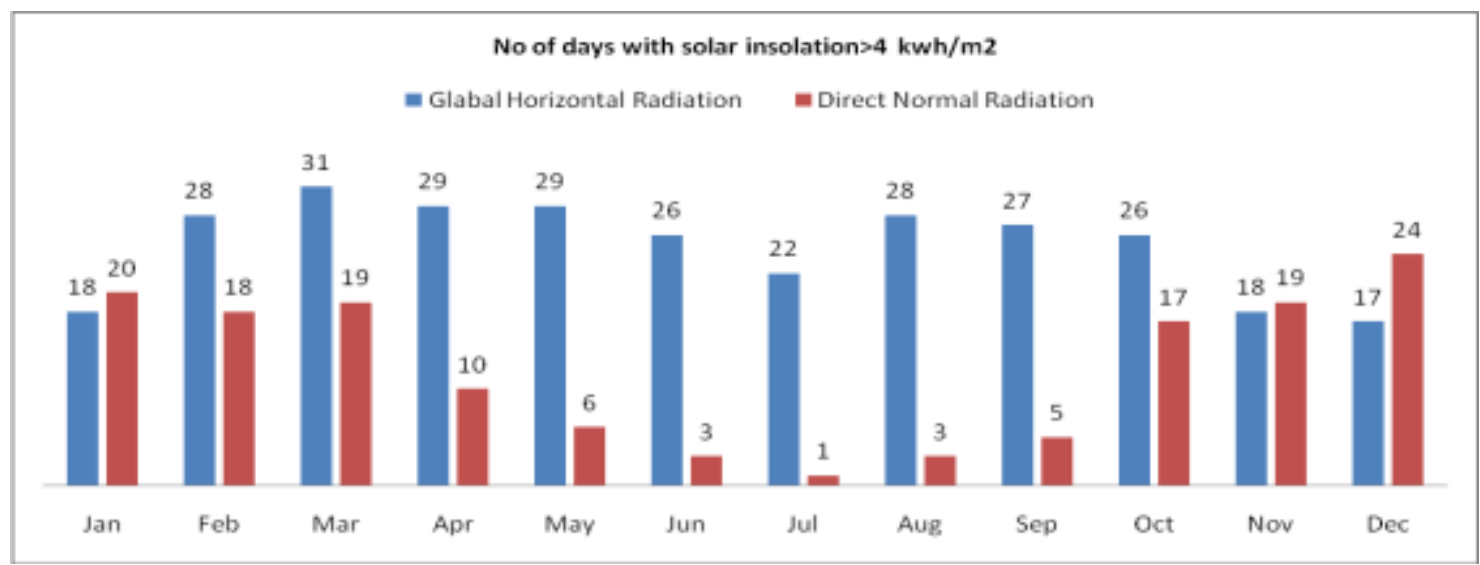

Fig.15 Number of days a solar cooker can be used

Solar cookers mainly depend on direct radiation, although box cookers make use of both direct and diffused radiations. Hence, on average, solar cookers can be used on 145 days per annum. As on June 2010, the annual consumption of natural gas by the domestic sector is 80.20 billion cubic feet. The total number of gas connections is $2,325,456$ which mean that on average, each household with gas connection uses about 34,488 cubic feet of natural gas per annum and 94.49 cubic feet of gas per day. If such a household uses a solar cooker on every sunny day, it is possible for that household to save about $94.49 \times 145=13,701$ cubic feet of natural gas per annum. [27]

2.3.3 Obstacles of solar cooking:

Despite the many advantages that solar cooking can bring about in the lives of Bangladeshi people, there are several obstacles to successful deployment of solar cookers over a countrywide range. The obstacles are discussed below:

- Lack of flexibility: Solar cooking can be done only in the presence of sun and with necessary solar insolation Moreover; solar cooing takes longer to cook food than conventional methods.

- Limited Access to Sunlight: Although rural people in Bangladesh may still get plenty of sunlight for cooking, very few residents of the city area have access to sunlight for solar cooking purpose

\section{Conclusion:}

Solar insolation is the most abundant renewable energy source of Bangladesh. Taking advantage of it we can enrich our regular life. In this paper we have tried to focus on the alternative uses of solar energy to ensure the energy security in near future. A solar based electric vehicle recharging station can reduce the fossil fuel consumption in transportation sector without using any power from grid and will keep our environment clean. A DC grid in off grid area based on solar PV can solve our irrigation problem as well as will ensure a better life for the rural people. Solar cooking can be a viable option for cooking both in rural and city area for reducing the natural gas consumption and burning of wood stock. So by ensuring these prospects we can solve our energy and gas crisis; and ensure a green environment for the future generations. 


\section{Reference}

[1] Norman Mariun, Sayed Zahurul Islam "Global Scenario of Renewables and challenges to meet the future energy demand"

[2] An Assessment of Solar Energy Conversion Technologies and Research Opportunities, GCEP Energy Assessment Analysis Summer 2006

[3] SHAKIR-ul haque Khan, TOWFIQ-ur-Rahman, SHAHADAT Hossain.'A brief study of the prospect of solar energy in generation of electricity in Bangladesh' Cyber Journals: Multidisciplinary Journals in Science and Technology, Journal of Selected Areas in Renewable and Sustainable Energy (JRSE), June Edition, 2012

[4] Last day of access (February19, 2013)[Online] Available http://www.wisegeek.com/what-is-solar-thermal-energy.htm

[5] H R Ghosh, S M Ullah, S K Khadem, N C Bhowmik and M Hussain "Measurement and Estimation of sunshine duration for Bangladesh" Renewable Energy Research Center, University of Dhaka, Bangladesh

[6] Last day of access (February18, 2013)[Online] Available http://solartradingpost.com/solar-angle-calculators.html

[7] Muhammad Hager Mollah an Analysis, Design and Opportunity of Solar Based Recharging Stations for Electric Vehicles in Bangladesh. Conference paper on "the developments in Renewable Energy Technology, (ICDRET '12)" January 2012 Dhaka Bangladesh

[8] Last day of access (February18, 2013)[Online] Available http://www.altestore.com/store/Enclosures-Electrical-Safety/Electrical Enclosures/Combiner-Pass-Through-Boxes/Midnite-Solar-MNPV3-Combiner-Box/p4567/

[9] Ecology Information Document 'Cost analysis for pollution prevention', Publication Number 95-400 Revised, October 2002

[10] Last day of access (February 9, 2013) [Online] Available http://www.prothom-alo.com/detail/date/2013-02-04/news/326462

[11] K. M. Mustafizur Rahman “Electricity Scenario in Bangladesh” November 2011

[12] Islam Sharif (Infrastructure Development Company Limited (IDCOL) "RENEWABLE ENERGY DEVELOPMENT IN BANGLADESH” Madrid, Spain October 19-23-2009

[13] M. Rofiqul Islama, M. Rabiul Islamb, M. Rafiqul Alam "Renewable energy resources and technologies practice in Bangladesh" Received 30 June 2006; accepted 31 July 2006

[14] Khalid Md. Bahauddin ,Tariq M.d Salahuddin Himel, Nayma Iftakhar "Impact of Solar Home System to Meet Energy Crisis and Contribute to Poverty Alleviation in Rural Areas of Bangladesh" Conference paper on "the developments in Renewable Energy Technology, (ICDRET '12)" January 2012 Dhaka Bangladesh

[15] Ahammed and Taufiq "Applications of Solar PV On Rural Development in Bangladesh" - Journal of Rural Community Development 3 (2008) 93-103

[16] M. Rezwan Khan "Prospect of Solar PV Based Irrigation in Rural Bangladesh" Conference paper on "the developments in Renewable Energy Technology, (ICDRET '12)” January 2012 I Dhaka Bangladesh

[17] Last day of access (February 9, 2013) [Online] http://www.energybangla.com/2012/12/20/2457.html

[18] T. Givler and P. Lilienthal "Using HOMER $®$ Software, NREL's Micropower Optimization Model, to Explore the Role of Gen-sets in Small Solar Power Systems” Technical Report NREL/TP-710-36774 May 2005

[19] Last day of access (June 23, 2012). [Online] http://itouchmap.com/latlong.html

[20] Last day of access (February 11, 2013). [Online] https://maps.google.com.bd/

[21] Last day of access (February 11, 2013). [Online] www.nrel.gov/visitors_center/pdfs/appliancesamperage.pdf

[22] M.Kay and N.Hatcho "Small scale pumped irrigation: Energy and cost "Food and agricultural organization of united nations, Rome 1992.

[23] Md Tanvir Arafat Khan, Md Rishad Ahmed, Sina Ibne Ahmed, Shahidul Islam Khan Design and Performance Analysis of Water Pumping Using Solar PV. Conference paper on "the developments in Renewable Energy Technology, (ICDRET '12)" January 2012 Dhaka Bangladesh

[24] Last day of access (February 11, 2013). [Online] http://homerenergy.com/

[25] Last day of access (February 11, 2013). [Online] http://vision-batt.eu/products/6fm200d-x-0

[26] Last day of access (February 11, 2013). [Online] http://www.solarcooker-at-cantinawest.com/solarcookers-types.html

[27] Tanzila Hosna Alam, Shahriar Ahmed Chowdhury "Solar Cooking and Its Prospects in Bangladesh" Conference paper on "The developments in Renewable Energy Technology, (ICDRET '12)" January 2012 Dhaka Bangladesh

[28] Ahammed and Taufiq "Applications of Solar PV On Rural Development in Bangladesh" - Journal of Rural Community Development 3 (2008) 93-103 